\title{
INTERACTION OF QUADRUPLE BONDING RHENIUM UNIT WITH FREE RADICALS ${ }^{\S}$
}

\author{
Shtemenko A.V., Tretyak S.Y., Golichenko A.A. \\ Ukrainian State Chemical Technology University, 49005 Ukraine Dnepropetrovsk, Gagarina av.8 \\ E-mail: ashtemenko@yahoo.com Phone: +38(0562)47-06-72. Fax: +38(0562)47-33-16.
}

\begin{abstract}
The interaction of cis- $\mathrm{Re}_{2}(\mathrm{RCOO})_{2} \mathrm{Cl}_{4}$, trans- $\mathrm{Re}_{2}(\mathrm{RCOO})_{2} \mathrm{Cl}_{4}, \mathrm{Re}_{2}(\mathrm{RCOO})_{3} \mathrm{Cl}_{3}$ and $\mathrm{Re}_{2}(\mathrm{RCOO})_{4} \mathrm{Cl}_{2}$ (where $\mathrm{R}$ - alkyl group) with 1,3,5-triphenylverdazyle radical in 1,2-dichlorethane was investigated. It is discovered, that gradual substitution of halogenide ligands by carboxylates in dirhenium(III) clusters led to slowing down of reaction with a radical due to different influence of these ligands on parameters of rhenium - rhenium bond. Presented data showed perspectivity of $\mathrm{Re}_{2}{ }^{6+}$-substances applications as therapeutic agents due to their low toxicity and antiradical properties that occured by $\delta$-component of quadruple Re-Re bond electron transition.
\end{abstract}

Keywords: rhenium, cluster, quadruple bond, free radical, antiradical activity.

\section{INTRODUCTION}

It was revealed earlier, that a majority of dirhenium(III) halocarboxylates synthesized by us had low toxicity and different kinds of biological activity [1-5]. The binuclear cluster $\mathrm{Re}_{2}{ }^{6+}$ - fragment is a part of these compounds and includes multiple rhenium - rhenium bond with $\delta$-component [6], which plays the role of free radical "scavenger" [3] by virtue of minor energy $\delta-\delta^{*}$ cleavage $(0,615 \mathrm{eV}[7])$. One of the specific problems is the search and investigation of substances displaying simultaneously antihemolytic and antiradical activity as the activation of free - radical processes accompany most pathological states [8]. In this connection therefore an actual study of interaction of derivatives cluster $\mathrm{Re}_{2}{ }^{6+}$ with stable free radicals is both important and preferential. The interaction of a series of dirhenium(III) derivatives with 1,3,5-triphenylverdazyle radical (Vd) was investigated. The Vd-radical was synthesized according to procedure [9], subsequently upgraded by the writers. The 1,2-dichlorethane was selected as a solvent for carrying out investigations, since parent compounds possess good solubility. Also it possesses low electron-donating properties $\left(\mathrm{DN}\left(\mathrm{SbCl}_{5}\right)=0\right)$ [10], therefore the solvent does not react with a radical.

Vd-radical transfers to triphenylverdazyle-cation upon transition of an electron (Fig.1).<smiles>c1ccc(PC2=NC(c3ccccc3)=NN(c3ccccc3)C2)cc1</smiles>

Vd - radical Vd-cation

Fig.1. 1,3,5-triphenylverdazyle radical and its cation.

Such type of transition may be explored with the help of electronic absorption spectra(EAS), as the maximum absorption is characteristic for Vd-radical at $13900 \mathrm{~cm}^{-1}$ and $25000 \mathrm{~cm}^{-1}$, and for cation $-18180 \mathrm{~cm}^{-1}$ [9]. With the help of EAS it is also possible to show the availability of a quadruple bond rhenium - rhenium in dirhenium(III) halocarboxylates in the visible region using $\delta-\delta^{*}$-electron transition $[11,12]$. Thus, the electronic spectroscopy is a reliable method for studding transmutations in system $\mathrm{Vd}$ - derivatives $-\mathrm{Re}_{2}{ }^{6+}$.

The interaction of a Vd-radical with all possible structural types dirhenium(III) halocarboxylates $\left(\mathrm{Re}_{2}(\mathrm{RCOO})_{4} \mathrm{Cl}_{2}\right.$, $\mathrm{Re}_{2}(\mathrm{RCOO})_{3} \mathrm{Cl}_{3}$, cis- $\mathrm{Re}_{2}(\mathrm{RCOO})_{2} \mathrm{Cl}_{4}$, trans- $\mathrm{Re}_{2}(\mathrm{RCOO})_{2} \mathrm{Cl}_{4}$, where $\mathrm{R}$ - alkyl group) was studied by EAS spectroscopy.

Study of interaction of Vd-radical with dihalotetra- $\mu$-carboxylates of dirhenium(III)

The compounds $\mathrm{Re}_{2}(\mathrm{RCOO})_{4} \mathrm{Cl}_{2}$ (where $\mathrm{R}=\mathrm{C}_{2} \mathrm{H}_{5}, \mathrm{C}_{3} \mathrm{H}_{7}, \mathrm{i}_{-} \mathrm{C}_{3} \mathrm{H}_{7}, \mathrm{C}_{10} \mathrm{H}_{15}$ ) (Fig.2) were selected for investigation. The structure and properties of these compounds were learnt earlier $[13,14]$.

\footnotetext{
$\S$ Material presented at the XV-th Conference "Physical Methods in Coordination and Supramolecular Chemistry", 


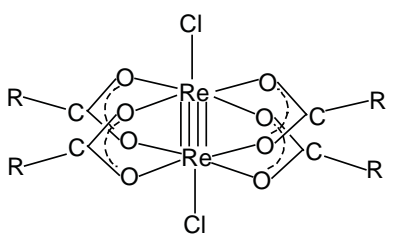

(where R - alkyl group)

Fig. 2. Structure of dirhenium(III) dihalotetra- $\mu$-carboxylates.

Interaction of dihalotetra- $\mu$-acetate of dirhenium(III) with a Vd-radical was not investigated, because this compound is not dissolved in most organic solvents.

Investigation of dihalotetra- $\mu$-carboxylates of dirhenium(III) $\left(\mathrm{R}=\mathrm{C}_{2} \mathrm{H}_{5}, \mathrm{C}_{3} \mathrm{H}_{7}, \mathrm{i}-\mathrm{C}_{3} \mathrm{H}_{7}, \mathrm{C}_{10} \mathrm{H}_{15}\right)$ has allowed the calculation of dependence of reaction rate from the length of alkyl groups and their bifurcation in cluster dirhenium(III) compounds. Study of a derivative of 1-adamantanecarboxylic acid $\left(\mathrm{R}=\mathrm{C}_{10} \mathrm{H}_{15}\right)$ was stipulated by the uniqueness of adamantane-group structure (Fig.3) This ligand belongs to the class of carcass ligands, which represents by itself three soldered cyclohexane rings in conformation chair (Fig.3).

It has a very high induction effect, even greater, than that of tert-butyl group that confirmed higher values of electrical dipole moments for adamantane derivatives. An example of that was showed earlier on chlorides of this group: $\mu\left(\mathrm{C}_{10} \mathrm{H}_{15} \mathrm{Cl}\right)=2,32 \mathrm{D}$, and $\mu\left(\left(\mathrm{CH}_{3}\right)_{3} \mathrm{CCl}\right)=2,13 \mathrm{D}[15,16]$.

\section{E-}

Fig. 3 Structure of adamantane group.

A mixture of $0,0079 \mathrm{~g} \mathrm{Re}_{2}\left(\mathrm{C}_{3} \mathrm{H}_{7} \mathrm{COO}\right)_{4} \mathrm{Cl}_{2}\left(9,9 \cdot 10^{-6} \mathrm{~mol}\right)$ and $0,0062 \mathrm{~g} \mathrm{Vd}\left(2,07 \cdot 10^{-5} \mathrm{~mol}\right)$ was soluble in $25 \mathrm{ml} 1,2-$ dichlorethane and recorded EAS of an obtained solution in time. As a result, disappearance of maximums characteristic for parent compounds (Fig.4) and appearance of a maximum absorption at $18180 \mathrm{~cm}^{-1}$ in EAS describing formation of $\mathrm{Vd}$ - cation, which took place. Tetracarboxylate derivatives reacted with a radical within 30-35 days.

The changing EAS (Fig.4) confirms the transfer of electrons from a Vd-radical to $\operatorname{Re}_{2}{ }^{6+}$ - group, thus the $\mathrm{Re}-\mathrm{Re}$ bond's order is decreased.

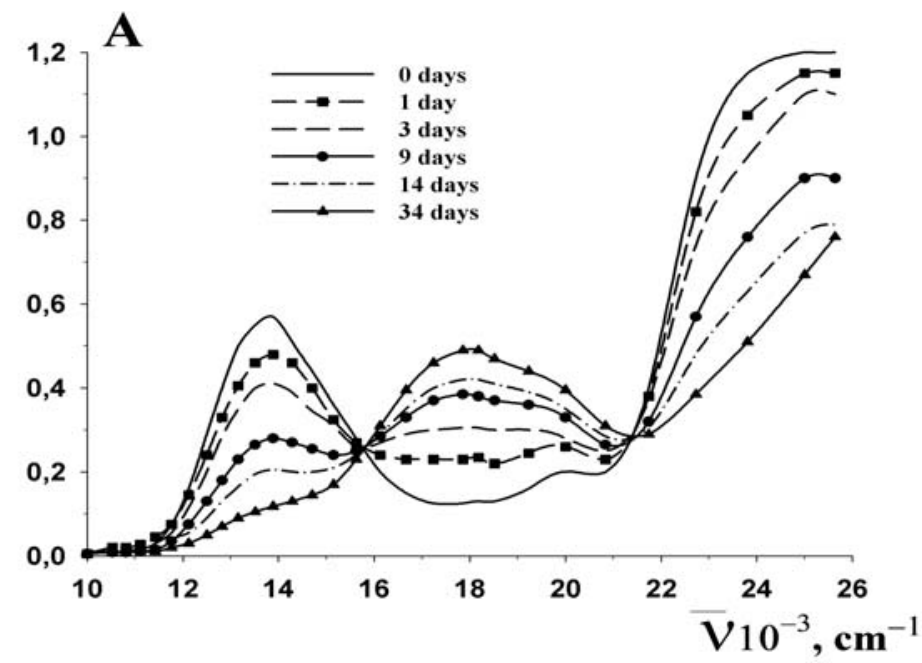

Fig. 4. EAS in 1,2-dichlorethane Vd with $\mathrm{Re}_{2}\left(\mathrm{C}_{3} \mathrm{H}_{7} \mathrm{COO}\right)_{4} \mathrm{Cl}_{2}$.

As was displayed previously in results of the kinetic investigation [17], the reaction rate decreased when increase of induction effect in carboxylate group $\left[\mathrm{J}\left(\mathrm{C}_{10} \mathrm{H}_{15}^{-}\right)>\mathrm{J}\left(\mathrm{i}-\mathrm{C}_{3} \mathrm{H}_{7}-\right)>\mathrm{J}\left(\mathrm{C}_{3} \mathrm{H}_{7}-\right)>\mathrm{J}\left(\mathrm{C}_{2} \mathrm{H}_{5}-\right)\right.$. Thus for adamantane derivative it is observed to have the least reaction rate with a Vd-radical. Increasing of branching of alkyl groups (for example, $\mathrm{C}_{3} \mathrm{H}_{7}$ and $\mathrm{i}-\mathrm{C}_{3} \mathrm{H}_{7}$ ) lead to decreasing of the reaction constant, that is in accord with the major induction effect of the branched group $\mathrm{i}-\mathrm{C}_{3} \mathrm{H}_{7}$.

Study of interaction of a Vd-radical with trihalotri- $\mu$-carboxylates of dirhenium(III)

Interaction of compounds $\mathrm{Re}_{2}(\mathrm{RCOO})_{3} \mathrm{Cl}_{3}$ [6] (Fig.5) with 1,3,5-triphenylverdazyle radical in 1,2-dichlorethane was investigated. 


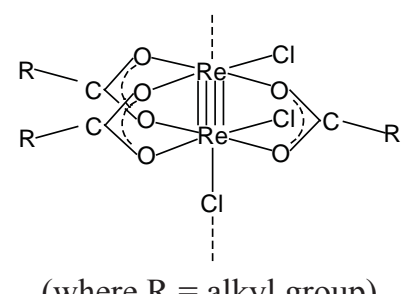

Fig. 5. Structure of $\mathrm{Re}_{2}(\mathrm{RCOO})_{3} \mathrm{Cl}_{3}$.

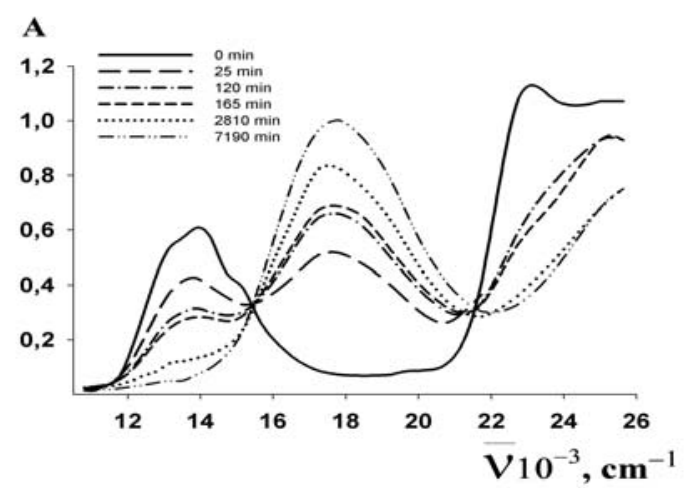

Fig. 6. EAS in 1,2-dichlorethane $\mathrm{Vd}$ with $\mathrm{Re}_{2}(\mathrm{RCOO})_{3} \mathrm{Cl}_{3}$.

$0,0026 \mathrm{~g} \mathrm{Re}_{2}\left(\mathrm{C}_{2} \mathrm{H}_{5} \mathrm{COO}\right)_{3} \mathrm{Cl}_{3}\left(3,7 \cdot 10^{-6} \mathrm{~mol}\right)$ and $0,0023 \mathrm{~g} \mathrm{Vd}\left(7,6 \cdot 10^{-6} \mathrm{~mol}\right)$ is dissolved in 1,2-dichlorethane, then obtained solutions is mixed and recorded change EAS in time (Fig.6).

The spectral data (fig.6) show that in time absorption maximum at $13890 \mathrm{~cm}^{-1}$ disappear and the maximum of absorption at $18180 \mathrm{~cm}^{-1}$ appears and is increased in intensiti, that confirms conversion of Vd-radical to Vd-cation [9]. Similar results were obtained for other trihalotri- $\mu$-carboxylates of dirhenium(III). Interaction of a Vd-radical with tricarboxylate derivatives took place within several days (Fig.6).

\section{Study of interaction of a Vd-radical with cis-tetrahalodi- $\mu$-carboxylates of dirhenium(III)}

Cis-tetrahalodi- $\mu$-carboxylates of dirhenium(III) (Fig.7) are stable enough in solid state in air for a long time and soluble in many organic solvents and inorganic acids [11].

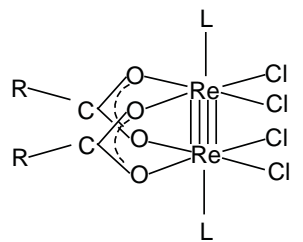

(where $\mathrm{L}=$ DMFA, $\mathrm{R}$ - alkyl group)

Fig. 7. Structure of cis- $\mathrm{Re}_{2}\left(\mathrm{CH}_{2} \mathrm{COO}\right)_{2} \mathrm{Cl}_{4} \cdot 2 \mathrm{DMFA}$.

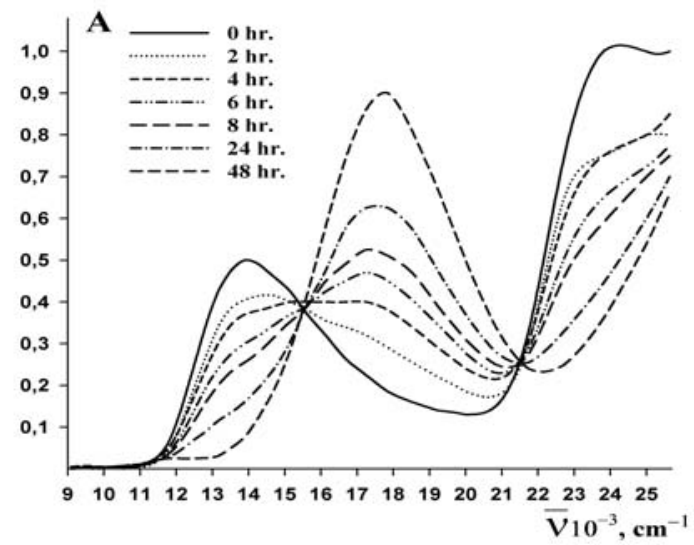

Fig. 8. EAS in 1,2-dichlorethane Vd with cis- $\mathrm{Re}_{2}\left(\mathrm{CH}_{3} \mathrm{COO}\right)_{2} \mathrm{Cl}_{4} \cdot 2 \mathrm{DMFA}$. 
$0,0044 \mathrm{~g}$ cis- $\mathrm{Re}_{2}\left(\mathrm{CH}_{3} \mathrm{COO}\right)_{2} \mathrm{Cl}_{4} \cdot 2 \mathrm{DMFA}\left(5,6 \cdot 10^{-6} \mathrm{~mol}\right)$ and $0,0035 \mathrm{~g} \mathrm{Vd}\left(1,1 \cdot 10^{-5} \mathrm{~mol}\right)$ were dissolved in $12 \mathrm{ml}$ of 1,2-dichlorethane, then mixed obtained solutions and record change EAS in time. The interaction of a Vd-radical with cis-tetrahalodi- $\mu$-carboxylates of dirhenium(III) in dichlorethane took place within days. The disappearance of absorption maximum in parent compounds took place in visible region and appearance of absorption maximum of $\mathrm{Vd}-$ cation (Fig.8) confirmed complete finishing of the reaction.

\section{Study of interaction of a Vd-radical with trans-tetrahalodi- $\mu$-carboxylates of dirhenium(III)}

Trans-tetrahalodi- $\mu$-carboxylates of dirhenium(III) (Fig.9) represents a significant interest both from the theoretical and applied aspects $[18,19]$.

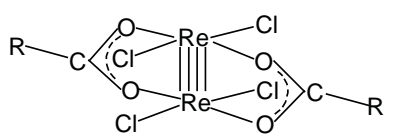

(where $\mathrm{R}=$ alkyl group)

Fig. 9. Structure of trans- $\mathrm{Re}_{2}(\mathrm{RCOO})_{2} \mathrm{Cl}_{4}$.

The interaction of $0,0062 \mathrm{~g}$ of a Vd-radical $\left(20,7 \cdot 10^{-6} \mathrm{~mol}\right)$ with $0,0073 \mathrm{~g}$ of a trans- $\mathrm{Re}_{2}(\mathrm{RCOO})_{2} \mathrm{Cl}_{4}\left(10,6 \cdot 10^{-6} \mathrm{~mol}\right)$ in $25 \mathrm{ml}$ of dichlorethane took place within several seconds, which was confirmed by the EAS data. The compounds were separately dissolved in 1,2-dichlorethane. Trans- $\mathrm{Re}_{2}(\mathrm{RCOO})_{2} \mathrm{Cl}_{4}$ and Vd-radical have, accordingly, blue (absorption maximum at 12500 and $16129 \mathrm{~cm}^{-1}$ ) and green colour (absorption maximum at $13900 \mathrm{~cm}^{-1}$ ) (fig. 10). After mixing of both compounds, the colour of the resultant solution then immediately changed to violet.

Such conclusion is confirmed by EAS data (Fig.10), which clearly indicates the disappearance of maximums, specific for parent compounds and appearance of a maximum absorption at $18180 \mathrm{~cm}^{-1}$ describing formation of $\mathrm{Vd}-$ cation.

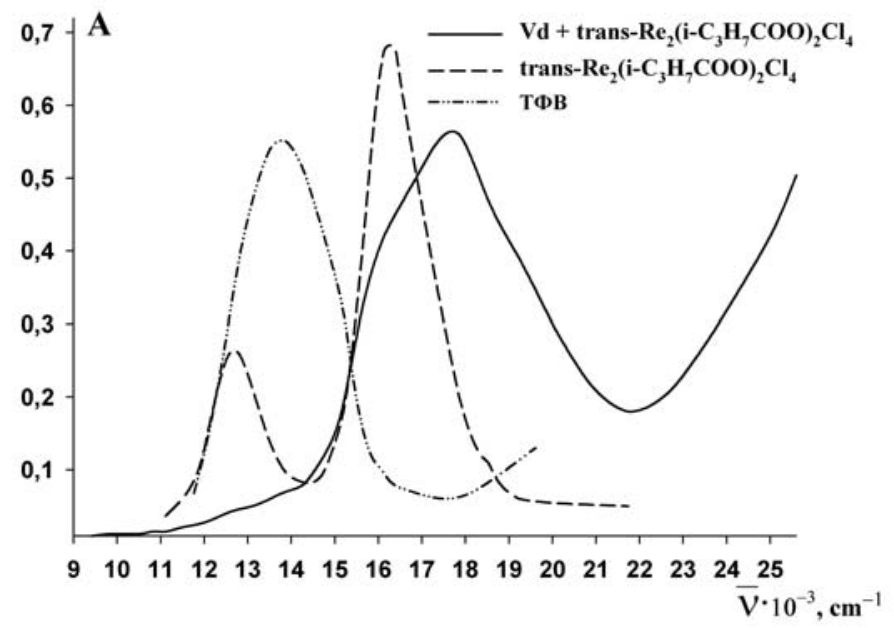

Fig. 10. EAS in 1,2-dichlorethane Vd with trans- $\mathrm{Re}_{2}\left(\mathrm{i}-\mathrm{C}_{3} \mathrm{H}_{7} \mathrm{COO}\right)_{2} \mathrm{Cl}_{4}$.

\section{CONCLUSIONS}

The interaction of all possible structural types of halocarboxylate derivatives of the cluster $\operatorname{Re}_{2}{ }^{6+}$ with $1,3,5-$ triphenylverdazyle radical was studied. The reaction finished completely due to interaction of the compounds with twofold molar excess of a Vd-radical [20]. In these conditions disappearance of absorption bands, which were relevant to origin substances and appearance of $\mathrm{Vd}$ - cation bands took place in electronic absorption spectra. Disappearance of the maximum absorption, which characterizes $\delta$ - $\delta^{*}$-electron transition confirmed cleavage of $\delta$-component of quadruple bond Re-Re.

Analysis of the obtained results shows that binuclear cluster fragment $\operatorname{Re}_{2}{ }^{6+}$ actively reacted with Vd-radical, however the rate of such interaction strongly depends on the charge ratio and ligand environment of the cluster $\mathrm{Re}_{2}{ }^{6+}$.

It was shown, that a gradual substitution of halogenide ligands by carboxylates in dirhenium(III) clusters led to the slowing down of the reaction with a radical due to different influence on these ligands by the parameters of rhenium - rhenium bond. The least reaction rate is showed for tetracarboxylate derivatives. Besides, the reaction rate decreased with an increase of induction effect of alkyl groups. This fact may be explained by stronger pressing-in of electronic density to rhenium - rhenium bond, for which the effect of conjugation with COO-group and formation of pentamerous cycle was observed together with strengthening of the bond. 
Presented data showed positive future prospects for application of $\mathrm{Re}_{2}{ }^{6+}$-substances applications as therapeutic agents due to their low toxicity and antiradical properties that occurred by $\delta$-component of quadruple Re-Re bond electron transition.

\section{REFERENCES}

[1] лійник С.А., Штеменко Н.І., Горчакова Н.О. та ін. Современные проблемы токсикологии. 2001, 1, $11-15$.

[2] Eastland G.W. Jr, Yang G., Thompson T. Methods. Find. Exp. Clin. Pharmacol. 1983, 7, 435-438.

[3] Олійник С.А, Штеменко Н.І., Пірожкова І. В. та ін. Доповіді НАН України. 2001, 7, 176-180.

[4] Штеменко Н.И., Пирожкова-Паталах И.В., Штеменко А.В., Голиченко А.А. Укр.биохим.журнал. 2000, 3 , $77-81$.

[5] Штеменко Н.I., Олійник С.А., Штеменко О.В. та ін. Доповіді НАН України, 2001, 6, 194-198.

[6] Cotton F.A., Walton R.A. Oxford: Clarendon Press. 1993, 780.

[7] Bursten B.E., Cotton F.A., Fanwick P.E., Stanley G.G. J.Am.Chem.Soc. 1983, 105, 3082-3087.

[8] Гриневич Ю.П., Олійник С.А., Штеменко Н.І., Штеменко О.В. Укр.біохім.журн. 2003, 1, 50-56.

[9] Полумбрик О.М. Химия вердазильных радикалов; Наукова думка: Киев, 1984; с.25-46.

[10] Гутман В. Химия координационных соединений в неводных средах; Мир: Москва, 1970; с.30.

[11] Shtemenko O.V., Bovykin B.A. Rhenium and Rhenium Alloys; TMS Publication: Pensilvania, 1997; pp.189 197.

[12] Штеменко А.В., Голиченко А.А., Кожура О.В. Вопросы химии и хим. технологии. 2000, $2,21-24$.

[13] Cotton F.A., Oldham C., Robinson W.R. Inorg. Chem. 1966, 10, 1798-1804.

[14] Shtemenko A.V., Golichenko A.A., Domasevitch K.V. Z. Naturforsch. 2001, 4/5, 381-385.

[15] Багрий Е.И. Адамантаны : получение, свойства, применение; Наука: Москва, 1989; с.188-190.

[16] Мажейка И.Б., Янковская И.С., Полис Я.Ю. Ж.общ.химии. 1971, 7, 1633-1635.

[17] Голиченко А.А., Третяк С.Ю., Штеменко А.В. Вопросы химии и хим. технологии. 2006, 6, 22-24.

[18] Штеменко А.В., Багиров Ш.А., Котельникова А.С. и др. Журн. неорган. химии. 1981, 1, 111-114.

[19] Shtemenko O.V. Rhenium and Rhenium Alloys; TMS Publication: Pensilvania, 1997; pp.173 - 178.

[20] Штеменко А.В., Голиченко А.А., Третяк С.Ю. Вопросы химии и хим. технологии. 2005, 5, 37-39. 